\title{
A STUDY OF SEISMIC POUNDING BETWEEN ADJACENT BUILDINGS
}

\author{
Ravindranatha ${ }^{1}$, Tauseef M Honnyal ${ }^{2}$, Shivananda S.M ${ }^{3}$, H Suresh ${ }^{4}$ \\ ${ }^{1}$ Assistant Professor (selection grade), Civil Engineering, Manipal Institute of Technology, Karnataka, India. \\ ${ }^{2}$ Post Graduate student, Structural Engineering, Manipal Institute of Technology Manipal, Karnataka, India \\ ${ }^{3}$ Structural Engineer (Underground Metro), GEODATA INDIA Pvt lmt, Bangalore, Karnataka, India \\ ${ }^{4}$ Managing Director, Structural Engineer, Civil Tech India Pvt lmt, Bangalore, Karnataka, India.
}

\begin{abstract}
Seismic pounding between adjacent buildings can cause severe damage to the structures under earthquakes, when owing to their different dynamic characteristics. During earthquake, the buildings vibrate out of phase and at rest separation is deficient to accommodate their relative motions. Such buildings are usually separated by expansion joint which is insufficient to provide the lateral movements of the buildings during earthquakes. It can be prevented by providing safe separation distances, sometimes getting of required safe separations is not possible in metropolitan areas due to high land value and limited availability of land space. If building separations is found to be deficient to prevent pounding, then there should be some secure and cost effective methods to prevent structural pounding between adjacent buildings. There are many buildings which are constructed very nearly to one another in Metropolitan cities, because everyone wants to construct up to their property line due to high cost of land. This study covers the prevention techniques of pounding between adjacent buildings due to earthquakes. Constructing new RC walls, cross bracing system and combined $R C$ wall \& bracing, with proper placement are proposed as possible prevention techniques for pounding between adjacent buildings.
\end{abstract}

Keywords: Seismic Pounding, Earthquake, SAP2000, Prevention of structural Pounding, RC wall, Bracings. $* * *$

\section{INTRODUCTION}

Investigations of past and recent earthquake damage have illustrated that the building structures are vulnerable to severe damage and collapse during moderate to strong ground motion. Damage has illustrated several instances of pounding damage (3.Sudhir K Jain et.al, 2001) in both building and bridge structures. Pounding damage was observed during the 1985 Mexico earthquake, the 1988 Sequenay earthquake in Canada, the 1992 Cairo earthquake, the 1994 Northridge earthquake, the 1995 Kobe earthquake and 1944 Elcentro earthquake. Significant pounding was observed at sites over $50 \mathrm{~km}$ from the epicenter, thus indicating the possible catastrophic damage that may occur during future earthquakes having closer epicenters. Pounding of adjacent buildings could have worse damage as adjacent buildings with different dynamic characteristics which vibrate out of phase and there is insufficient separation distance (1.Abdel and Shehata, 2006). Past seismic codes did not give definite guidelines to preclude pounding, due to economic considerations including maximum land usage requirements, especially in the high density populated areas of cities, there are many buildings worldwide which are already built in contact or extremely close to another, that could suffer pounding damage in future earthquakes. A large separation is controversial from both technical [difficulty in using expansion joint and economical loss of land usage] views (2. A Hameed et.al, 2012). The highly congested building system in many metropolitan cities constitutes a major concern for seismic pounding damage. The most simplest and effective way for pounding mitigation and reducing damage due to pounding is to provide enough separation, but it is sometimes difficult to be implemented due to high cost of land. An alternative to the seismic separation gap provision in the structure design is to minimize the effect of pounding through decreasing lateral motion. The main objective and scope is to evaluate the effects of structural pounding on the global response of building structures, to determine the minimum seismic gap between buildings and provide engineers with practical analytical tools for predicting pounding response and damage.

\section{METHODOLOGY}

To observe pounding, a three dimensional reinforced concrete moment resisting frame buildings with open ground floor is taken and analyzed in SAP2000. The two buildings consist of eight stories $(\mathrm{G}+8)$ and five stories $(\mathrm{G}+5)$. All columns in all models are to be fixed at the base. The height of all floors is $3.2 \mathrm{~m}$. Slab of eight stories and five stories is modeled as rigid diaphragm element of $140 \mathrm{~mm}$ and $130 \mathrm{~mm}$ thickness respectively, for all stories considered. Live load on floor is taken as $3 \mathrm{kN} / \mathrm{m} 2$ and on roof is $1.5 \mathrm{kN} / \mathrm{m} 2$. Floor finish on the floor is $1 \mathrm{kN} / \mathrm{m} 2$ and weathering course on roof is $1 \mathrm{kN} / \mathrm{m} 2$. The seismic weight is calculated conforming to IS 18932002(part-I). The unit weights of concrete is taken as $24 \mathrm{kN} / \mathrm{m} 3$ The grade of concrete for column is M-25 and for 
beam and slab is M-20.The building is special moment resisting frame considered to be situated in seismic zone IV having medium soil and intended for residential use. These buildings are separated by expansion joint of $80 \mathrm{~mm}$. Both buildings are analyzed in SAP2000 and are designed as per IS 456-2000. Both buildings are subjected to gravity and dynamic loads. To observe pounding, Time History Analysis is carried out taking data of Elcentro.

Building-1 ( $\mathrm{G}+8)$ has 3 bays in $\mathrm{X}$ and $\mathrm{Y}$ directions, having corner columns dimension of $0.3 \times 0.6 \mathrm{~m} 2$, whereas all inner columns are of $0.3 \times 0.75 \mathrm{~m} 2$. Width of each bay in $\mathrm{X}$ direction is $3.5 \mathrm{~m}$, and that of in $\mathrm{Y}$ direction is $4.5 \mathrm{~m}$, while the beam size is $0.3 \times 0.45 \mathrm{~m} 2$ in both the direction. Building $-2(\mathrm{G}+5)$ has 3 bays in $\mathrm{X}$ and $\mathrm{Y}$ directions, width of each bay in $\mathrm{X}$ direction are $3 \mathrm{~m}$, in $\mathrm{Y}$ direction it is $4.5 \mathrm{~m}$, having outer column dimension of $0.23 \times 0.45 \mathrm{~m} 2$, whereas all inner column are of $0.3 \times 0.45 \mathrm{~m} 2$. Beam size is $0.23 \times 0.45 \mathrm{~m} 2$ in both the direction. Pounding is considered in top floor of G+ 5 story i.e. at fifth floor, for observation Positive displacement of eight stories and negative displacement of five stories is considered, as we are going for worst condition due to its different dynamic characteristics

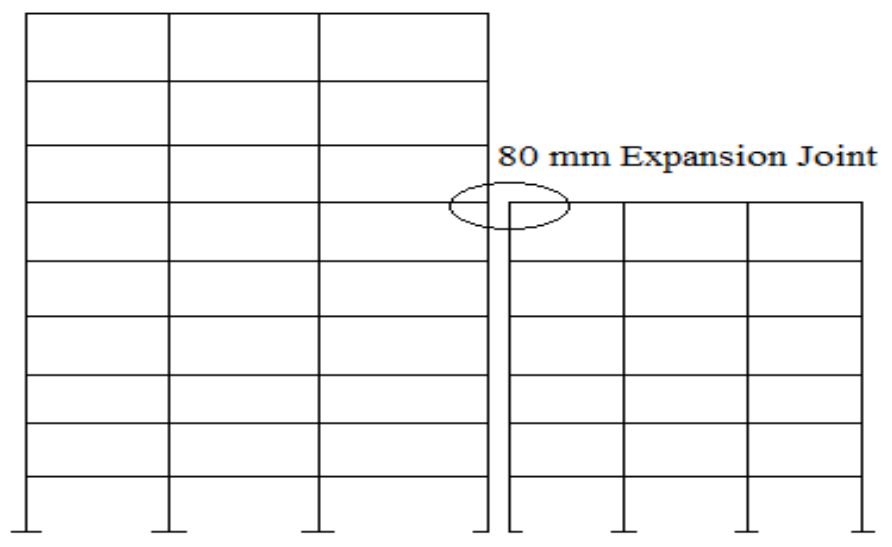

\section{PREVENTION MEASURES TO AVOID POUNDING:}

\subsection{Providing Proper Separation Gap:}

As pounding is observed at fifth floor due to positive displacement of eight story and negative displacement of five story buildings To prevent this, FEMA-273(Federal Emergency Management Agency) provides safe separation distances between adjacent buildings.

$\$=\sqrt{ }\left(\mathrm{Q}_{1}{ }^{2}+\mathrm{Q}_{2}{ }^{2}\right)$ is a SRSS (Square Root of the Sum of the Squares) Method

Where,

$\mathrm{Q} 1$ = highest displacement of building -1

Q2 = highest displacement of building -2

$\$$ should not be greater than the distance between adjacent buildings.

$$
\$=\mathrm{Q}_{1}+\mathrm{Q}_{2} \text { is Absolute Method }
$$

Where,

$\mathrm{Q}_{1}=$ highest displacement of building-1

$\mathrm{Q}_{2}=$ highest displacement of building-2

Fig-1: Represent the Position of Adjacent Buildings.

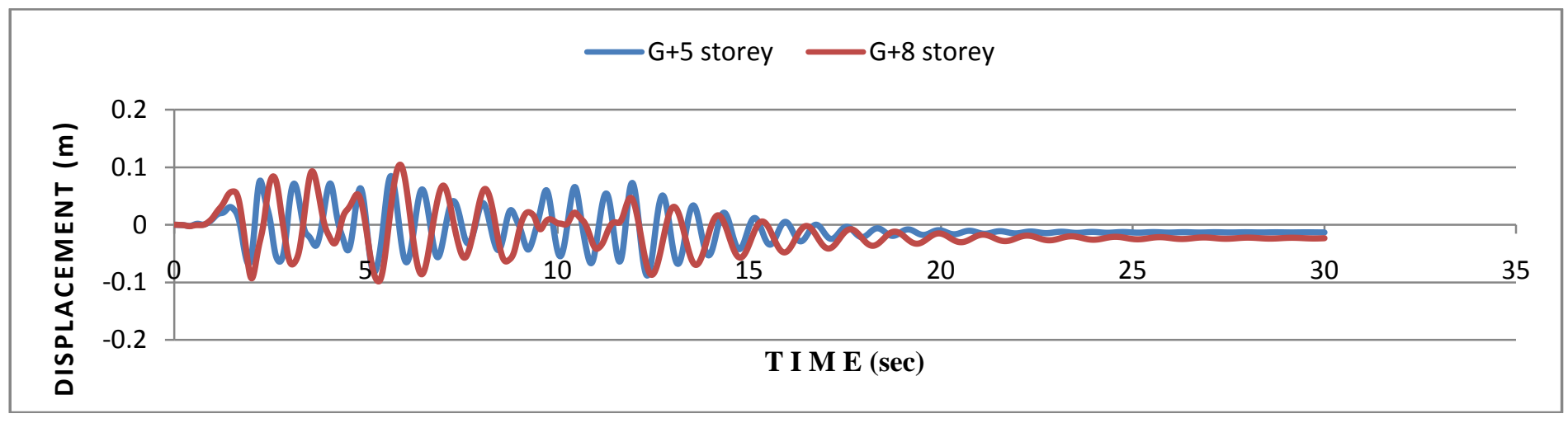

Fig-2: Time vs displacement graph of both buildings at $5^{\text {th }}$ floor level when there is no additional stiffness in buildings. 
After analyzing these two buildings in SAP2000 under Time History data of Elcentro which is to be known as above average earthquake, the buildings were observed displacement with respect to time. For pounding observance we are considering worst condition by taking positive displacement of G+ 8 story and Negative displacement of G+ 5 story due to different dynamic characteristics. This figure shows that maximum negative displacement of $\mathrm{G}+5$ story building at fifth floor level is $88.52 \mathrm{~mm}$ at $12.34 \mathrm{sec}$. The figure also shows that maximum positive displacement for $\mathrm{G}+8$ story building is $104.2 \mathrm{~mm}$ at $5.88 \mathrm{sec}$. From figure it is noticed that maximum out of phase movement of both building at $5.8 \mathrm{sec}$ is $(104.2+85.5)-80=109.7 \mathrm{~mm}$ which is greater than expansion joint, hence the separation joint between the buildings is $80 \mathrm{~mm}$ which is unable to accommodate this out of phase movement, and adjacent buildings will strike or collide at this time for about $29.7 \mathrm{~mm}$.

\subsection{Provide Cross Bracings to Increase Stiffness:}

Since gap between the buildings cannot be increased to accommodate the relative movement of both the buildings, we can reduce the relative displacement by providing additional stiffness i.e. by bracings, shear wall and by combined action, to accommodate out of phase movement under provided gap. Cross Bracings are provided at the end panels of the both buildings to reduce the relative displacements. The connection of steel cross braces with concrete frame structure requires a very special consideration and the strong connection should be there to transfer the load from concrete frame to cross braces safely.

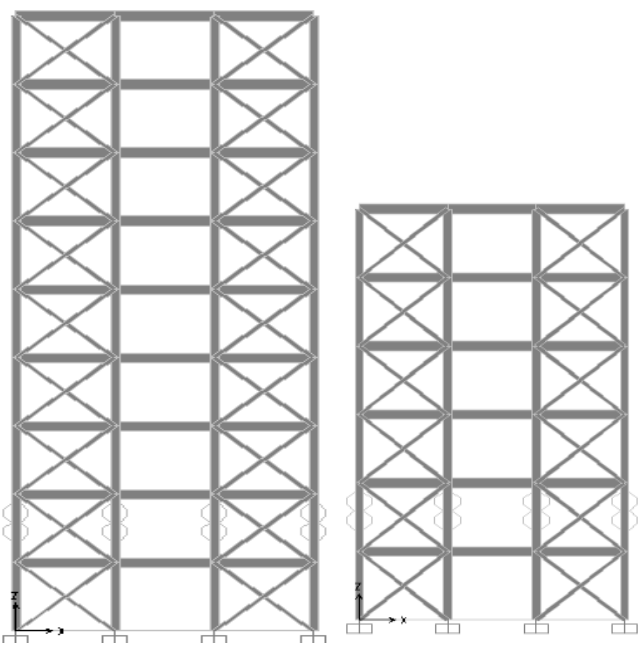

Fig-3: Shows the cross bracing of Eight story and Five story buildings

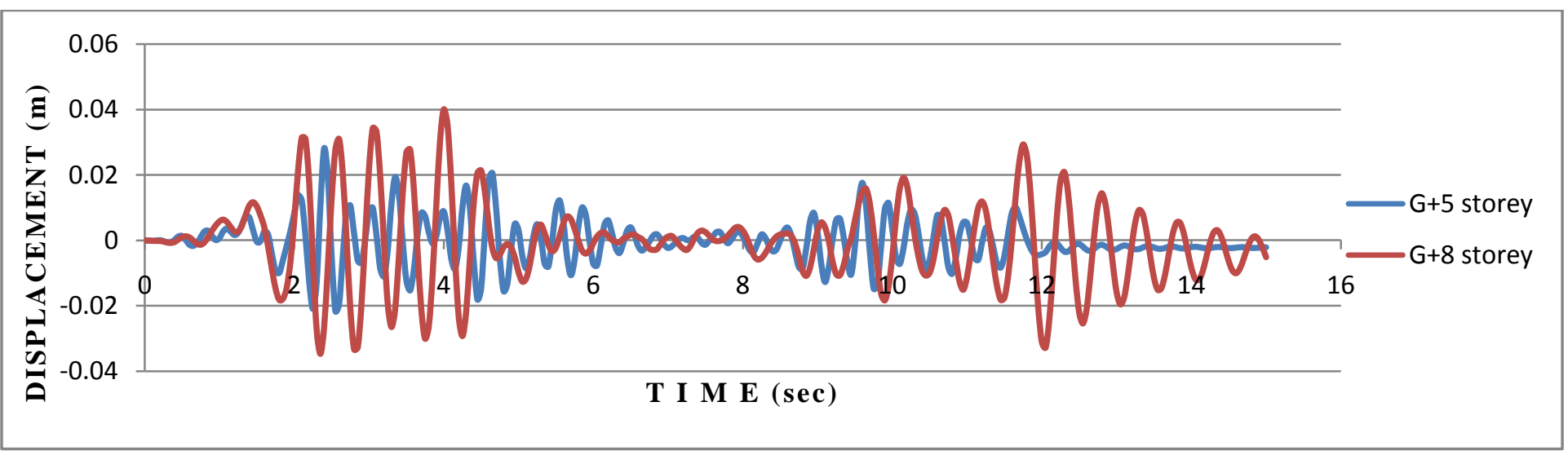

Fig 4: Displacement vs Time graph of both buildings at $5^{\text {th }}$ floor level when cross bracings are introduced in buildings.

Above figure-4, shows time vs displacement graph at $5^{\text {th }}$ floor level, in this Maximum Positive displacement of G+ 8 story at fifth floor is $40 \mathrm{~mm}$ at $4.00 \mathrm{sec}$ and Maximum Negative displacement of G+ 5 story is $21.56 \mathrm{~mm}$ at $2.55 \mathrm{sec}$. It shows that Maximum out of phase movement is $40+21.56=61.56 \mathrm{~mm}$ which is lesser than the expansion joint i.e. $80 \mathrm{~mm}$, hence No chance of pounding at any interval, when these kinds of additional stiffness is provided.

\subsection{Introducing New RC wall to Increase Stiffness:}

Shear walls are provided to reduce the lateral displacements in the buildings, here we are replacing masonry wall with RC wall.

Initially beams are designed for $(0.23 \times 20 \times 2.6=12 \mathrm{KN} / \mathrm{m})$ and now it is replaced by $0.18 \mathrm{~m}$ thickness of $\mathrm{RC}$ wall, hence the load on beam will be the same $(0.18 \times 24 \times 2.6=11.2 \mathrm{KN} / \mathrm{m})$. $\mathrm{RC}$ wall needs to be dowelled with the adjacent beams and 
columns to transfer lateral force safely to the ground.

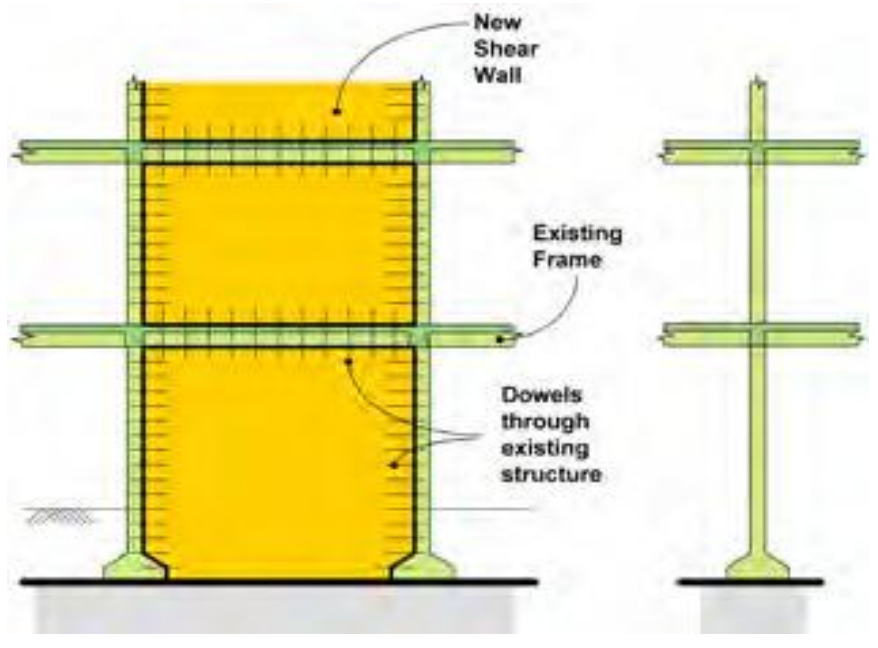

Here in this both the buildings, New RC walls are introduced in the mid panel of buildings to reduce lateral displacement of the buildings (11. Murthy, C.V.R, 2005). In G+ 8storey building, wall is of $3.5 \mathrm{~m}$ in $\mathrm{X}$ direction and in G+ 5 storey building, wall is of $3.0 \mathrm{~m}$ length in $\mathrm{X}$ direction. As we are interested to reduce the the lateral displacement in $\mathrm{X}$ direction were pounding can occur. Time History Analysis is done by taking Elcentro Earthquake data, to which time vs displacement graph plotted, to observe the displacements of both the buildings at fifth floor level.

Fig-5: Shows the dowelling of New RC walls through existing structure.

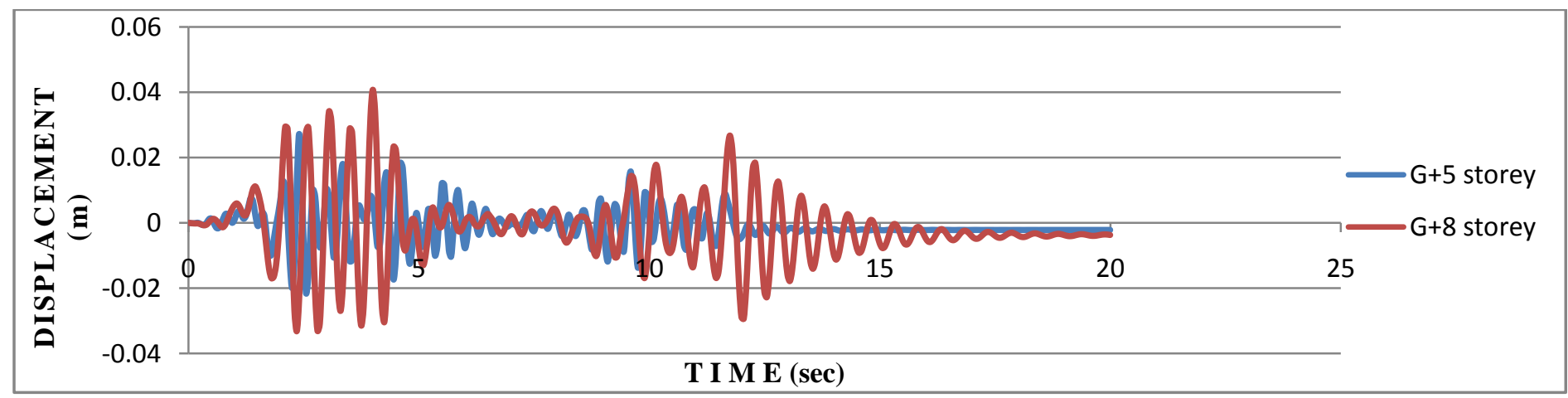

Fig-6:Shows the time vs displacement graph of both buildings at $5^{\text {th }}$ floor when shear wall is constructed.

From figure-6, it is noted that Maximum Positive displacement of Eight storey building is $40.76 \mathrm{~mm}$ at $4.00 \mathrm{sec}$ and Maximum Negative displacement of Five storey is 21.48 $\mathrm{mm}$ at $2.55 \mathrm{sec}$. Maximum out of phase movement is $40.76+21.48=62.24 \mathrm{~mm}$, it is less than expansion joint hence, no chance of pounding at any interval of time .

\subsection{Increasing the Stiffness by Combined Shear Wall and Bracing System:}

$\mathrm{RC}$ walls are provided at extrior mid panels and inner panels are placed by cross bracings in $\mathrm{x}$ direction for both the buildings, in order to prevent pounding between adjacent buildings.

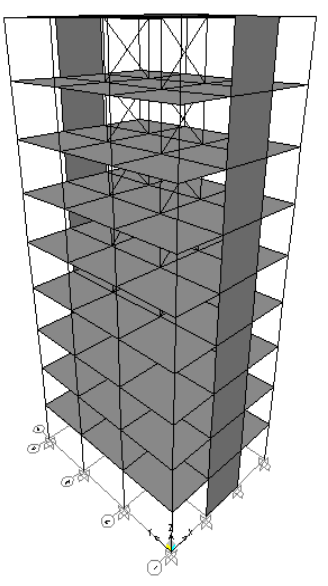

Fig-7: Shows the both $\mathrm{RC}$ wall are at exterior mid panel and cross bracing are in interior mid panels. 


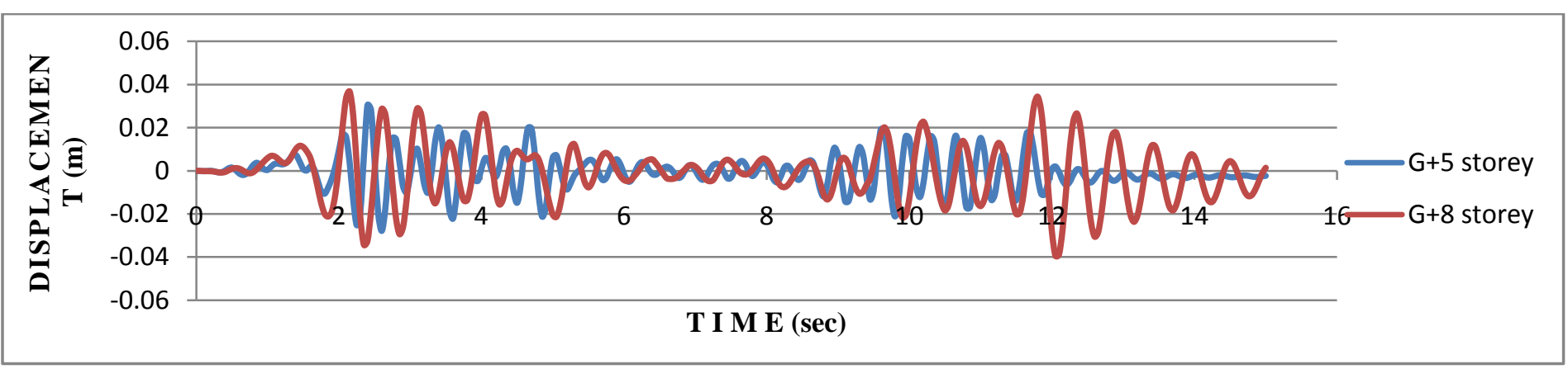

Fig-8: Shows time vs displacement graph for both buildings at $5^{\text {th }}$ floor level when both RC wall and cross bracings provided

From figure-8, it can be observed that Maximum Positive displacement of Eight storey at fifth floor is $36.7 \mathrm{~mm}$ at 2.15 sec and Maximum negative displacement of $\mathrm{G}+5$ storey is $27.84 \mathrm{~mm}$ at $2.6 \mathrm{sec}$. The absolute sum of both is $64.54 \mathrm{~mm}$. Hence it is also less than Expansion joint which is $80 \mathrm{~mm}$, no chance of pounding at any interval of time.

\section{CONCLUSIONS}

- At the time of design, designer have to ensure that there will be no pounding between adjacent buildings.

- Necessary safe separation gap should be provided according to FEMA-273.

- If buildings are old and are not in a stage toprovide safe gap, then prevention measure should be taken like this study had undertaken, using of New RC wall, cross bracing and combined system of both.

- Scope of this study is, replacing bracings with different dampers.

- All the prevention methods that are used in this study proved effective to prevent pounding between adjacent buildings.

- It is better to leave set back/safe separation gap according to FEMA-273, when the buildings are in early stage.

\section{ACKNOWLEDGEMENTS}

I would like to Thanks Almighty and especially to my father Mr. MURTUJA HONNYAL, my mother M/s FARIDA BANU HONNYAL and my dear brother's to their continuous Guidance, Inspiration and Support, which are the main factors behind any work. I take the pleasure of thanking all those who have helped, supported and gave constant encouragement throughout my work without whom, this work would not have been completed in time.

\section{REFERENCES}

[1] Abdel R and E.Shehata "Seismic Pounding between Adjacent Building Structures" Electronic Journal of Structural Engineering 66-74 (2006).
[2] A. Hameed, M. Saleem, A.U. Qazi, S. Saeed and M. A. Bashir "Mitigation of seismic pounding between adjacent buildings" Pakistan journal of science vol.64, December 2012.

[3] Sudhir K Jain et.al, "A field report on structural and geotechnical damages sustained during the 26 January 2001 M7.9 Bhuj Earthquake in Western India"

[4] IS 456:2000 "Indian Standard Plain and Reinforced Concrete Code of Practice".

[5] FEMA \pm 273 [1997] "NEHRP Guidelines for the seismic rehabilitation of buildings, Report No.FEMA \pm 273 ," Federal Emergency Management Agency, October.

[6] IS 1893 (Part 1):2002 Indian Standard "Criteria for Earthquake Resistant Design of Structures" Part 1 General Provision and Buildings, (Fifth Revision).

[7] ATC 40 [1996] "Seismic evaluation and retrofit of concrete buildings, Vol No.1 and"Applied Technology Council, Seismic Safety Commission, State of California.

[8] Robert Jankowski" Non-linear Modeling of Earthquake Induced Pounding of buildings"s published on ICTAM, 15-21 August 2004, Warsaw, Poland.

[9] Fabian R. Rojas, James C. Anderson and M.ASCE "Pounding of an 18-Story Building during recorded earthquakes" American Society of Civil Engineers, 2012.

[10] Murty, C.V.R "Earthquake Tips Learning and Earthquake Design and Construction". National Information Center of Earthquake Engineering, IIT Kanpur, India, September, 2005.

* SAP 2000 Nonlinear Version 14.0 Software Package.

* SAP 2000 Nonlinear Manuals.

* SAP 2000 Videos. 